\title{
Making Meaning of Empowerment and Development in Rural Malawi- International Individualism Meets Local Communalism
}

\author{
Johanna Sofia Adolfsson ${ }^{1}$, Sigrun Marie Moss ${ }^{2}$ \\ [1] Centre for Development and the Environment, University of Oslo, Oslo, Norway. [2] Department of Psychology, University of Oslo, Oslo, Norway.
}

Journal of Social and Political Psychology, 2021, Vol. 9(2), 623-636, https://doi.org/10.5964/jspp.7549

Received: 2020-01-14 • Accepted: 2021-04-05 • Published (VoR): 2021-12-07

Handling Editor: Puleng Segalo, University of South Africa, Pretoria, South Africa

Corresponding Author: Johanna Sofia Adolfsson, Postboks 116, Blindern, 0317 Oslo, Norway. E-mail: j.s.adolfsson@sum.uio.no

\begin{abstract}
Empowerment is a prominent concept in psychology, and for decades, it has been a key term in global development policy, theory, and practice. However, in line with similar turns toward individualism in psychology, the prevalent understanding of the concept centers on individual capacity to change circumstances, with less focus on empowerment as a context-dependent or communal approach. In this article, adopting decolonial feminist psychology as a lens, we analyze how rural Malawians make meaning of the overarching empowerment and development approach of non-governmental organizations (NGOs) working in their villages, and how they perceive the approaches as fitting with local contexts. When development implementers largely ignore Malawi's communal lifestyle, individualized empowerment initiatives can lead to individual and communal disempowerment and distress. Given psychology's large influence on other arenas, and psychology's implication with the individualized gender-developmentempowerment nexus, we argue that it is imperative to explore the effects and experiences of this empowerment approach in different contexts. A more context-appropriate understanding of empowerment-as with most other psychological concepts-is needed.
\end{abstract}

\section{Keywords}

decolonial feminist psychology, coloniality of empowerment, global development gender policies, NGOs, sub-Saharan Africa

As a dominant discipline in modern society, psychological theory and method permeate and influence many domains, discourses, and practices (Madsen, 2014). Notable is the predominance of the concept of empowerment. For decades, 'women's empowerment' has been among the top policy goals of bodies such as the UN and the World Bank, as evident in the UN Global Millennium Development Goal 3 (MDG3) and the 2015 UN 2030 Agenda. The latter includes Sustainable Development Goal 5 (SDG5): to "achieve gender equality and empower all women and girls." (Sustainable Development Goals Knowledge Platform, 2020). This global policy's focus on women's empowerment has inspired large-scale developmental interventions designed to empower women to escape poverty, mainly through educational initiatives (Pincock, 2018). However, the contextual and communal aspects of empowerment theorized by some community psychologists (see Nelson \& Prilleltensky, 2010; Rappaport, 1987), is rarely debated or practiced by development actors (Cornwall \& Anyidoho, 2010; Klein \& Ballon, 2018). Rather, the dominant focus on the individual, prevalent in many Western psychological traditions (Adjei, 2019), has come to play a substantial role in development policy, theory, and practice (Klein, 2016). This is particularly manifested in non-governmental organizations' (NGOs) general tendency to center implementation of empowerment on individuals' agency and capacity to change their own circumstances (Cornwall \& Anyidoho, 2010; Rutherford, 2018); and less on systemic alterations or communal interventions. In Malawi, many NGOs especially target rural communities for women and girls' empowerment, with individualized activities such as entrepreneurship-, vocational skills training, and education. Using fieldwork data from two rural Malawian 
communities, and adopting a decolonial feminist psychology lens, we ask, how villagers see the overarching approaches of the NGOs, and how they perceive the NGO approaches as fitting with local context. Our material indicates that communal, rather than individualistic, approaches to empowerment in development interventions would be a better fit with the social realities in question. The aim is not to pass judgment on specific NGOs, nor do we discuss specific interventions. Instead we explore overarching aspects the villagers brought up regarding the NGOs (such as the objectives of the NGOs and how and whom they select as beneficiaries), aiming to engage in important discussions of empowerment and context. The material provides opportunities to analyze and question the lack of context sensitivity in psychology-informed development work. This article thus speaks to the calls for more "context appropriate" (Adjei, 2015) approaches and research on community empowerment (see Keys, McConnell, Motley, Liao, \& McAuliff, 2017). In line with the decolonial feminist psychology stance, we emphasize our own positionality from the get go: being white, female Scandinavian researchers writing about mainly western NGOs lack of context-sensitivity in development work in Malawi, we want to emphasize two aspects: first, that the project was conducted in close collaboration with Malawians (both research assistant, and through active discussions with counterparts at the University of Malawi Chancellor College). Second, that our presentation and analysis-despite our active engagement with the context-ultimately still will be influenced by our closeness to Scandinavian forests and fjords, rather than to the Malawian plains and highlands. The article should be read with this in mind.

\section{The Coloniality of Development and Empowerment}

Empowerment approaches focusing on marginalized individuals and groups' psychological, political, sociological, organizational, and economic wellbeing have often been valued for their focus on collective resistance and action against structural inequality and political oppression (Nelson \& Prilleltensky, 2010; Rappaport, 1987). Particularly, empowerment has been fronted as a way for women to organize, gain power and control, and "to challenge and eliminate their own subordination" (Adjei, 2015, p. 62). However, critiques note that in practice, such collective approaches have lost ground within social psychological science (Phillips, Adams, \& Salter, 2015), and arguably also within community psychology (Keys et al., 2017). Feminists psychologists argue that the Western discourse of individualization has been distributed-in the name of empowerment-and promoted by international development actors as the standard model for global South women and girls' self-actualization, yet with no incentives for larger structural and political transformations (Kiguwa \& Segalo, 2019; Rutherford, 2018; Távara, 2019). Additionally, while designed for marginalized women, these women generally have little or nothing to say in how "their empowerment" is organized. Nevertheless, many would accept the aid as they are in need (Segalo, Manoff, \& Fine, 2015). Moreover, post-colonial critique coming from global South writers, argue that NGOs' 'aid' and 'development' missioning is a camouflaged colonial project (Sakue-Collins, 2021; Shivji, 2007). Taking a decolonial feminist psychological approach, we thus position ourselves within the stance that the development enterprise promotion of interventions modeled on hegemonic Western norms of neoliberal individualismlike individualized and gendered empowerment interventions-are manifestations of coloniality (Estrada-Villalta \& Adams, 2018, p. 205). That is, when hegemonic Western ways of being, seeing and knowing are continuously reproduced and decreed as standard norms, and imposed on non-Western societies-often ex-colonies-at the expense of their ways of being, seeing, and knowing (Grosfoguel, 2002; Maldonado-Torres, 2007; Mignolo, 2007; Quijano, 2000). As such, decolonial feminist psychological approaches, as we adopt here, challenge "models of the self that emphasize individual empowerment and abstraction from the context" (Estrada-Villalta \& Adams, 2018, p. 204). Stressing the importance of critical decolonial psychology theory and action-research Segalo and Fine (2020, p. 5) maintain, "Decoloniality as a theory, as epistemology, and as an approach assists us to make sense of challenges that continue to confront us as humanity as a result of coloniality." In this paper, using decolonial feminist psychology as a lens, our objective is to illuminate the coloniality of the prevailing "individualized empowerment ideology". Looking at how Western (psychological) assumptions of development and individualism travel through NGOs in the language of 'empowerment', we ask rural Malawians targeted by these development practices, how they make meaning of them. 


\section{The Malawian Context}

Some $84 \%$ of Malawi's population of around 18 million live in rural areas (WHO, 2019) depending predominantly on subsistence farming (Anderson, 2015). In 2010, 50\% of the population were living below the poverty line, with $25 \%$ defined as extremely poor, unable to cover their nutritional needs (IMF, 2017). Low economic security and its linkage to NGOs is described by Swidler and Watkins (2017, p. xv) as "In a world of dire scarcity, of urgent struggles simply to live, villagers rationally adapt themselves to virtually any program, however nonsensical, that holds out even a hope of material gain." This creates a patron-client relationship where the patron defines supply and demand, and the clients cannot question either. Malawian women do the major part of unpaid labor (MacIntyre et al., 2013) and largely depend on men for economic support (Verheijen, 2013). This leaves women with little influence over domestic, social, and political decision-making (Anderson, 2015; MacIntyre et al., 2013). Women's subordinate role makes them more vulnerable to HIV infection, structural and sexual violence, and with less access to necessities, literacy, and higher education (Anderson, 2015; MacIntyre et al., 2013; National Statistical Office [NSO], 2008). Nearly one third of Malawian girls aged 15-19 have been or are pregnant (NSO Malawi \& ICF, 2017), and one out of two quit school before completing primary education (UNESCO, 2013). Many NGOs concentrate-in line with the SDG5's global agenda-on empowerment as a way of equipping women and girls with tools for making "better choices" and "achieving better lives" (Adolfsson \& Madsen, 2020). NGO activities focus on behavior change training in vocational skills, cash transfer programs, HIV prevention, education, and family planning (Baird, Chirwa, McIntosh, \& Özler, 2010; Watkins \& Swidler, 2013). Scholars on Africa have noted how the Zulu Ubuntu expression "a person is a person through other persons" captures the communal African understanding of the self (Adjei, 2019; Baloyi \& Ramose, 2016). Given the communal principle, the individual personhood is morally dependent on reciprocal relations with others, which obligate family and friends to share and support each other in times of hardship (Sagner \& Mtati, 1999)-ideals essential in societies lacking formal security nets (Lwanda, 2005). This embedded inter-dependence and connectedness with the communal forms the very understanding of the self (Kurtiş \& Adams, 2015; Mkhize, 2004; Ogbonnaya, 1994).

\section{Method}

To explore how rural Malawian villagers saw the overarching approaches of the NGOs, and how such approaches were seen as fitting with local contexts, we conducted thirty-four informal interviews; five focus group discussions (FGDs) and six in-depth interviews in a rural district of southern Malawi. We collected the data between April and August 2017. The fieldwork was carried out by the first author together with "Hannah", an experienced Malawian cultural guide and research assistant with extensive fieldwork experience in ethnographic methods.

\section{Location and Population}

The research was conducted in two neighboring rural villages selected in collaboration with the local authorities. The people live primarily from informal trade, piecework, and small-scale farming. Many participants were illiterate. Many reported having to struggle to cover their basic needs. One chief oversaw both villages. According to the chief, there were ten NGOs operating in the villages at the time of our study, with projects ranging from deforestation and agriculture, to cash transfer and savings/loans, orphanages, empowering girls, school attendance, and household development (including training in family planning, food storage, long-term planning). Informants emphasized that most projects focused on teenage pregnancies and female empowerment through vocational training and education. To avoid our project being confused with the NGOs operating in the area, Hannah based herself in the villages 14 weeks before the first author arrived. This enabled villagers to learn about our project and us as researchers. Hannah visited all households in both villages and conducted informal interviews only after establishing rapport. Visiting all the households-Hannah informed us-was important for not stirring up suspicions between households or villages. Hannah's stay and the first author's arrival were cleared with the chief; and their roles as researchers and the study's focus on NGOs development and empowerment approaches was presented to him and to the villagers. Hannah spent 
her days in the villages but lived elsewhere. When the first author arrived, she and Hannah shared accommodation in a nearby town, for three months, over two periods in 2017.

\section{Sampling}

Hannah's daily interaction with the community during the initial 14 weeks allowed her to reach out to all 34 households. At least one person from each family was interviewed. As the NGOs empowerment programs generally target women and girls-and us being particularly interested in hearing their voices-24 of the 34 informal interviews Hannah conducted were with female community members. All participants were aged 18 to 50 and above (after which they were not interested in specifying age), and worked as small-scale farmers, and with various informal business.

\section{Interview Schedule}

All interviews were conducted in Chichewa (national language) and/or the local language Chiyao (villagers understood some or most of both languages). All interviews centered on topics concerning women's and girls' empowerment, development, individualized interventions, individual success, jealousy, cultural practices, and witchcraft. All participants had reflections and definitions of what 'development' meant to them. Most participants were also familiar with the concept of 'empowerment'. First, Hanna conducted the 34 informal interviews. Rather than scheduled in beforehand, these were often done in an organic way, and often while Hannah participated in the villagers' daily tasks. Hannah took notes during the interviews, later written up at home. Each interview lasted around an hour. From these 34 informal interviews, the first author and Hannah selected a sample of participants who they thought would be interested in participating in FGDs, based on their experiences and reflections on the discussed themes. We conducted five FGDs: two FGDs with four and six female participants respectively, age-span 30 to 50 and above in both groups; two FGDs with mixed-gender young adults with three women and three men in each; and finally, five men aged 30 to 50 and above in the last FGD. Our intention was to be able to grasp the nuances of experiences across gender and generations (see McLafferty, 2004). Subsequently, we invited a diverse sample of FGD participants to participate in in-depth interviews. We conducted six in-depth interviews with three women and three men. All in-depth interviews and FGDs were held in the villages' shared community house, all lasting between 30 and 60 minutes, and tape-recorded, with participants' consent. The questions were asked in English by the first author, and then translated by Hannah into Chichewa and/or Chiyao. Hannah wrote down the answers, immediately translating them into English. The first author followed up with questions in English, and so forth.

\section{Ethical and Methodological Challenges and Author Positionality}

Research permits were granted by the National Commission for Science and Technology in Malawi (NCST); the local District Council, the village authorities, as well as by the Norwegian Centre for Research Data (NSD). The main challenges concerned the fieldwork setting. Referred to (by participants) as an mzunga (directly transferred as white wealthy European woman [Pass, 2016]), the first author and Hannah (an educated English-speaking middle-class Malawian) could be associated with people working for NGOs. Thus, it was important that they established their positions as researchers, and to make clear what the study would entail and not. Hannah's lengthy stay in the villages before the first author's arrival proved helpful to avoid such role confusion. Yet, even though making explicit their researcher-roles, villagers asked them to bring forward their wishes to the NGOs. This reveals how whiteness, the English language, and elitism are powerfully associated with NGOs, and intrinsically rooted in historical colonial oppression, stressing the importance of reflecting over the effect of coloniality in intercultural meetings. Therefore, that Hannah could immerse herself in the setting for a lengthy period and collect much of the data, was important for establishing rapport. Her ability to also engage with participants in the local languages was crucial. This underscores the necessity (and joys) of working with local colleagues (Moss \& Hajj, 2020) and across race/nationality/class/global North and South power lines in development and in research (Segalo \& Fine, 2020). In writing up the research, both authors (being Scandinavian) acknowledge being far removed from the context. While both of us have lived and worked in different areas of sub-Saharan Africa, and have worked with colonial processes and decolonial stances, we acknowledge that we 
are embedded in our cultural context, which colors and structures how and what we see, feel, and think about the world. Therefore, this qualitative study and the analysis we present should be read as a subjective and constructed piece, and therefore one of many ways of seeing and interpreting social phenomena.

\section{Analysis and Results}

We analyzed the data using inductive thematic analysis (Braun \& Clarke, 2006), positioned within a social constructionist stance (Burr, 2015), where we see the accounts as subjective, but valid. The co-construction of meaning, by the various positionings in the villages and larger Malawi, as well as the co-construction of meaning by NGOs and donors within the larger neo-liberal lens, make such a stance a valuable approach for our project, as it holds that "the ways in which we commonly understand the world, the categories and concepts we use, are historically and culturally specific" (Burr, 2015, p. 4). In such we also acknowledge the positioning and co-construction of meaning that takes place between the participants and the research team as well. Both authors coded the material after in-depth and iterative readings, identifying recurrent topics and negotiations of specific relevance to the research topic. Interestingly, most participants mentioned the discrepancies between the positions of the villagers and the approaches of the NGOs. This led us to focus on the following: how do the participants talk about the approaches of the NGOs implementing development interventions in their villages? How do participants see the NGOs ways of operating as fitting with their settings? We read the material specifically for this, and constructed themes that we reworked through our discussions. We divide the analysis into two main themes. Theme I centers on power, as many of the participants reflected on their limited power to define their own realities vis a vis the NGO approaches. Theme II focuses on context. Here the participants directly and indirectly problematized NGO approaches (though not their presence), linked to how the villagers live their lives and the, at times, missing overlap between their context and the NGO approaches. The interview extracts are either recurrent topics brought up by many participants, or else demonstrate nuances and disagreements within the material. All participants were given pseudonyms.

\section{Theme I: Power}

When discussing the NGOs' overarching approaches, most participants brought up topics related to power. Who gets to decide what the projects entail? Who gets to decide who the beneficiaries of a project should be? Many of the participants talked of these decision-making processes as unclear, complex, and sometimes unjust, offering little agency to the villagers themselves. This can be linked to resistance. Participants expressed frustration over these processes, which may be regarded as what Scott (1990) calls hidden transcripts of resistance. Namely, subordinate groups' acts and expressions that represent "a critique of power spoken behind the back of the dominant" (p. xii). In Chichewa, empowerment translates to kupatsa mphamvu: the gaining of power (Pass, 2016). When asked about 'empowerment', participants generally linked this to power. Buseje, an older woman in one of our FGDs for example said that empowerment is having the right to speak out. When discussing empowerment related to the NGOs, it was particularly two topics that the participants brought up as issues they would have liked more room to speak out on: definitions of needs, and definitions of worthy recipients.

\section{Subtheme 1.1. Definitions of Need}

In Malawi, NGO projects are often designed according to pre-defined measures and demands from the donor (Swidler \& Watkins, 2017). Participants often mentioned that their needs and wishes for local projects often were different from those implemented by NGOs. Many participants discussed what they would have asked for if they had been able to influence processes prior to project implementation-in line with their definition of empowerment as involving the gaining of power. In the male FGD, Tambo explained his visions:

If I'd been involved with an NGO I'd have focused on good health in the community, made sure people have things like proper water, proper food and proper health care ... that we have enough medicine in the hospitals, maybe enough food at home. 
Here the focus is on tangible projects. Peter, in the same FGD, wanted other NGOs to come to the villages in addition to the ones there already, hoping that: "maybe they'd have projects that dealt with the people's needs." This indicates that the many NGOs that were currently involved in the village were not seen to be dealing with the actual needs of people. Similarly, interviewing Fanny, she said: "We want projects that can meet our needs, like something that can provide daily income." When asked if the villagers benefit from the NGOs, Liza explained: "We just accept, because the NGOs come to us and we can't choose the projects that we want." One of the most outspoken participants, Fatima, said: "If there was an NGO that focused on women by giving them loans, that would have been better, because then we have small businesses, and could contribute to village banking." Again, this quote shows sentiments of wanting and needing other approaches from the NGOs. Fatima emphasized the gendered aspects of one NGO's cash-transfer intervention:

The money we receive from [name of international NGO] ... When men are involved, they don't share the money with their wives, they share it with their girlfriends. There have been many secret marriages because of the money from [name of international NGO], and many pregnancies, because men have money to give these girls. But when we women receive the money, we go directly and buy food without letting our husbands know.

In explaining how the money from this NGO became a means for married men to engage in clandestine sexual relationships, Fatima did not blame the NGO for distributing the money to men. Instead, she blamed the men for their irresponsible behavior. Fatima wished for initiatives that could enable women to have control, and emphasized how "we women", in contrast to their husbands, spend the money sensibly rather than recklessly. This is particularly interesting as the NGO in question, like most NGOs in the area, advocates for women's empowerment. Fatima argued this initiative was yielding the opposite outcome. These excerpts indicate dreams and wishes as to what NGOs could achieve for the villagers. There were also definitions of empowerment that reflected a relatively passive stance in terms of needs. Edson, an older man in the male FGD, explained empowerment as a process of "telling people to do what they are supposed to do, but not forcing them." This may indicate the power asymmetry the participants have experienced from the NGOs, where they are frequently instructed as to "what they are supposed to do." Empowerment then becomes gaining the power not to be forced to do what you are supposed to. It is clear from the participants' accounts that they know what would make a difference in their lives, however "external aid often comes with predetermined directives that do not include Malawian perspectives or priorities" (MacIntyre et al., 2013, p. 105). This uneven power dynamic is evident in our data. Overall, wanting more agency in defining the needs of the community was prevalent in the interviews. Participants describe a process where their needs are not necessarily in accord with the projects established to improve the local situation, even resulting in unintended and contradictory outcomes. In terms of the overarching approaches of the NGOs, the participants also discussed which villagers should receive help.

\section{Subtheme 1.2. Definitions of Worthy Recipients}

Participants link empowerment to gaining power, but when it came to who was benefiting from the projects; accounts indicate stronger expressions of disempowerment than noted above. In the communal setting, participants spoke of the unequal division of goods. Based on the NGOs' pre-determined parameters (e.g., on gender, age, poverty level), people are included or excluded from projects. The premises for inclusion in a project are often not transparently explained, or the reasons might seem arbitrary to the villagers. Patience sees the selection process of who gets to benefit from an NGO project as random: "Those who are lucky, they're the ones who are very happy. They are lucky to be involved in those projects." Where all households live in extreme poverty (International Monetary Fund, 2017), the NGOs base their decisions on standards that the villagers would not necessarily agree with. The uneven distribution from the NGOs seemed to create resentment. Idah spoke bitterly of one of the NGOs operating in the villages:

I don't get chickens or goats, because the NGO doesn't give to everybody, they themselves choose who to give to, and that's corruption, the same person gets goats, chickens, and seeds, while others, they don't get anything.

Participants expressed frustration over this uneven approach. This resonates with Swidler and Watkins (2017) research on NGOs misunderstandings of the Malawian context, where Western ideals of individualism clash with local ideals of 
reciprocity and communality. Some participants emphasized that goods are divided based on needs, these were mostly people who had received goods themselves. In discussions of empowerment, there was a focus on how the NGOs were there mainly for women and girls, and particularly linked to education. Female participants generally agreed that this is important, but several of the men considered it unfair that the needs of women and girls were deemed more important than other groups. Tambo, father of three, in the male FGD, explained:

They [NGOs] always empower girls so that they should finish secondary school, they [the girls] should not get pregnant while they are studying. The NGOs always say that 'if you teach a girl child that means you have educated the world.'

This recital of such NGO rationales was common. A few men, however, did agree with this focus. Chiso, father of five children, said: "The NGOs mostly consider the girls. Of course, they make sure that everybody is educated, but they make sure that the girls come first." When asked if this were a good thing, Chiso said: "Yes, it is. If you help a girl child that means you help the world." Furthermore, young men in the mixed-gender FGD expressed concern over the uneven targeting of boys and girls. Kennedy for example said the NGOs' particular focus on the girls goes against gender equality where both sexes should be given equal opportunities. For these participants, it seemed unfair that the women were given advantages. It also seemed to tie into this notion that everyone should be helped equally. Kennedy for example thought the best solution would be to involve everybody in the NGO projects to "move forward together." This is interesting, while NGOs are campaigning gendered development policies like "achieve gender equality and empower all women and girls.", advocating for equal opportunities between the sexes in this communal setting, they contradict themselves by focusing solely on some. For NGOs operating at the rural level in Malawi, the local chiefs play an imperative role, as "they are the locus of village governance and possessors of much power. Simply to get an NGO project started, the chief has to approve" (Swidler \& Watkins, 2017, p. 210). The chief is customarily included in the selection of recipients of NGO interventions (Swidler \& Watkins, 2017), with the NGOs asking him for information on the various households (Swidler, 2013). Many of our respondents expressed frustration with the chief, often blaming him for the uneven distribution of goods. Idah for example held that receiving help from an NGO depends on your relationship with the chief: "The village chief decides who'll take part in the projects. We can be registered but at the end of the day, the chief will cross out our names and put in the names of people he knows." Here, Idah expresses a lack of influence-the non-gaining of power-concerning who will benefit from NGO projects. The chief himself expressed the dilemma of being caught between NGO project designs and his role as the village head:

NGOs come in and choose some target families, but the people don't understand. They may think that I'm the one who is greedy, that I'm the one who has chosen those people, they get jealous, and say that some are being targeted while others are not.

Violet agreed: "People they don't understand, they always think it is the chief's decisions." The NGOs' uneven and individualized distribution can lead others to see the recipients or the chief as greedy and selfish, behavior that is contrary to the ideal of reciprocal community life (Ferguson, 2006). Thus, the premises set by NGOs and their ignorance of local power-dynamics provide the chief with a position that potentially may stir up frustration and tension in the community. As the authority and credibility associated with chieftaincy is crucial for the village stability and sense of community (Ferguson, 2006), both the chief's authority and the community's well-being might be at stake if his credibility is questioned. Charles said the NGOs should handle the selection process themselves: "The NGOs go through the chiefs, and the chiefs decide who gets what. But if the NGOs themselves had come to our households, they'd have been able to see themselves how we live and how they can help us." If the NGOs were more closely involved, they would thus, according to Charles, see who needs help and what people need. There are elements of disempowerment in this first theme. Several participants expressed resentment at the lack of agency and transparency in these processes, and saw the NGOs overarching approach as lacking when it came to granting power to the villagers. Returning to Scott (1990), the frustration of the NGOs and the chief's power, expressed as corrupt and ignorant, can be interpreted as hidden transcripts of resistance. Here, accounts show how villagers are unhappy with how allocation of goods is managed. 


\section{Theme II. The Context}

Psychology as a discipline has been widely criticized for making too little of context (see Akomolafe, 2012; Mkhize, 2004). Similarly, in the international development sector, actors and agencies have often been regarded as promoting generic 'one size fits all' solutions to complex issues, which critics argue leaves context outside the broader picture (Adjei, 2015; Manuh \& Anyidoho, 2015). Contextual fit was something the participants brought up frequently, as they expressed that the NGO initiatives lacked understanding for their way of living. This theme is divided into two subthemes: communal life and negotiating communality with 'moving some forward'.

\section{Subtheme 2.1. Communal Life}

Participants generally talked about their setting as one of everyone, constantly using the pronouns "we", "us." Interconnectedness with others, such as village, extended family, peers, and neighbors, is particularly pivotal in communities that lack formal security systems. The reciprocal relations that people engage in safeguard them. The emphasis on the communal structure of their lives was often referred to in the interviews when discussing the NGOs overarching approaches. The participants for example linked their communal lives to their concept of development. The term for 'development' is chitukuko in Chichewa, (Pass, 2016), and across the interviews and FDGs, there was a shared, general understanding of development, as being related to community and unity, with everyone moving forward together. Asking participants in one of the mixed-gender FGDs what development means, Chisisi, a young man, told us "Development is about developing our households and it is also something that people do together." Alysha adding that "Maybe people in the community working together is part of development." Asked about development and the NGOs, the women in one FGD agreed that projects that did not include the whole village were not part of development. Sarah explained: "About the NGOs ... we can't say that they are part of development, no ... development is supposed to involve everybody." Here, the NGOs (Western) assumptions of individualism are up against local assumptions of communality. While promoting "development", the individualized focus of NGOs undermines their own role as development actors in these villages. One project frequently held up as an example of development was the NGO funded construction of the community building. The villagers were proud of this building which they used daily for activities ranging from Madrasa and nursery school to village meetings and as shelter from bad weather. Other often-mentioned examples of development included the well, the maize mill, the shared livestock house, and the orphanage. These communal structures were frequently contrasted with NGOs individualized interventions, which brings us to the next subtheme: where participants struggle with making sense of why only some are moved forward.

\section{Subtheme 2.2. Moving Some Forward}

Participants emphasized the importance of everyone "moving forward together", which was their core definition of development. However, this clashes with most NGO projects-that, according to our participants, mostly focus on moving some forward. In one of the mixed-gender FGDs, Leonard told us: "All I can say is that the NGOs, they shouldn't focus only on some ... when NGOs organize training, they shouldn't focus on adults only, while the youth are left out." This communal approach could be based on the general understanding of personhood, where life begins, centers and ends in communal life, often described as typical of African societies (Nwoye, 2015), where "individuality emerges and expresses itself communally" (Ogbonnaya, 1994, p. 79). While participants frequently mentioned this "moving forward together", many supported the view that those in greatest need should get more help (yet which, they added, was often not the case). Mostly however, participants wanted the allocated help distributed equally. Violet explained that people want communal approaches. When asked what happens when NGOs give help to only a few families, she said: "People don't accept this. They don't understand it, and ask: "why only these people, rather than focusing on everybody?" Moving only some forward, particularly when the selection process seems random and unfair, can lead to frictions. Many participants said that uneven distribution caused jealousy. Leonard, a young man in one of the mixed-gender FGDs, put it this way: "What happens in the village is that we always have jealousy, because for example, the NGOs can bring handouts but then it's not enough. If only the handouts could reach everyone, then there'd be no jealousy here." Leonard contrasted the NGO development approach with the villagers' communal and reciprocal way of understanding 
and living life, noting the negative consequences this had for social relations. Similarly, Mishal, a young woman in the same FGD, explained how development interventions in one village could fuel jealousy between the villages:

If, for example, an NGO comes, it would be good to focus on both villages, so that one village would not be jealous of the other. If it is only one village, the other village would be jealous ... But [one specific international NGO] covered the whole district, so there was no jealousy at all, because they reached everywhere.

When the principles of communality and reciprocity that Malawian society revolves around, are challenged by NGOs promoting individual progress, the local reciprocal bonds and social fabric may suffer. It was clear that jealousy is a very serious matter, stirring up resentment and threatening the social order. Yvonne explained that some could take their resentment and jealousy even further:

Others even think of using ufiti [witchcraft] because of jealousy, like "OK, that household is being targeted by the NGOs, while ours not, we are not getting anything. Why this household only?" That's when people start being jealous and may also turn to ufiti.

In Malawi, as elsewhere, people may relate themselves and their social world in connection to spiritual dimensions, such as ufiti (generally referred to as witchcraft), often manifested in practices closely linked to the communal life (Baloyi \& Ramose, 2016; Lwanda, 2005; Mgbako \& Glenn, 2011). Standard psychological models have generally considered such beliefs as related to pathological delusion, irrationality, or superstition (Adams, Estrada-Villalta, \& Ordóñez, 2018; Makhubela, 2016; Tembo, 1993). Yet, the fear of enemies and intrapersonal violence-such as envy, resentment, and ufiti-assaults--Adams et al. (2018, p. 19) assert, "is not a paranoid delusion, but instead reflects an accurate understanding of life in a fixed system of embedded interdependence." According to Scott (1990, p. 144), articulations of ufiti can also be seen as expressions of hidden transcripts of resistance, as "Witchcraft is in many respects the classical resort of vulnerable subordinate groups who have little or no safe, open opportunity to challenge a form of domination that angers them." Relatedly, in Lwanda's (2005, p. 262) research in Malawi, ufiti was linked to "corruption of normative taboos and conflicts amongst resources, personal need and communal order". In line with this, and the views expressed by many participants, Chiso, explained: "If you are selfish, that's when the ufiti comes" (see Adolfsson \& Moss, 2021). Combined, these two themes on power and context, speak to how Western individualization, so predominant in today's psychology and global development approaches, in this Malawian setting comes up against local communalism. The NGOs pre-set and top-down approach thus has the potential to contribute less to both development and empowerment. The individualized focus of the NGOs is complicated by sub-themes of the power theme above: participants feel they have no influence over what projects are chosen and carried out, nor can they influence the selection of beneficiaries. Viewing development as "everyone moving forward together" is rooted in values of communality, but also in the fact that everyone is desperately poor. When participants in one of the mixed-gender FGDs were asked if it would be better if NGOs focused on everyone, giving a little to all instead of more to some, the unison answer was "Yes!" The overarching approaches of most NGOs operating in the area thereby do not fit with local ideas of development or empowerment. The approach and process would need to involve "everyone moving forward together" for the participants to see many of these NGO projects as development, and for the villagers to be allowed more agency for there to be real empowerment. To empower women and girls is important-everywhere-but that needs to include asking them what they have to say in how their empowerment is organized, as well as taking contextual sensitivity seriously.

\section{Discussion}

Participants in our study saw empowerment as a communal way of gaining power and agency. Similarly, development was connected to moving the whole community forward. While it was widely held that the NGOs focused more on women and girls, the main concern expressed was not the gendered division, but the uneven targeting in general. Participants' accounts illustrate the collision between the communal and the individual, and the lack of agency. Empowerment as negotiated and understood by the villagers, in many ways reflects the community-based notions of 
the concept and speaks volumes to the emphasis on the importance of social context. The communal conception, we hold, is related to the reciprocal value, which serves as the social glue and security net in many societies. Participants' accounts emphasized this logic of sharing; however, precisely this essential interdependency is not recognized by the NGOs' way of distributing individualized support. The participants also called for more agency in influencing what projects should focus on for all to benefit and were generally unhappy with their lack of control in what was, for them, a random wheel of fortune. Their criticism of the NGOs approaches may be regarded as resistance. While participants said they were pleased with the NGOs being there, many criticized how they operate. Our findings indicate that, whereas the villagers had many thoughts as to how their community would best develop, the NGOs' pre-set and top-down approach could potentially disturb power dynamics and interdependence among individuals, and the community. The apparent unpredictability of NGOs approaches was in participants' accounts paired with little or no control over if, when, what, whom and how new projects might be set up to improve lives. Rather than the expected effect of empowerment and development, this may result in lack of agency and disempowerment. In sum, this prompts the question: when somebody else has defined your problems and their solutions, is it then empowerment? Empowerment, we hold, depends on the understanding and practice of being informed by the local reality in which it is implemented. In the light of our informants' understanding of empowerment as connected with power, and development as "moving forward together", we argue, in accordance with Estrada-Villalta and Adams (2018) that collective cooperation and participation towards common interests and goals are crucial aspects of community empowerment. Our analysis shows that individualized approaches may fuel suspicion, resentment, envy, and enmity among community members and between communities. Consequently, NGO interventions that follow an individualized logic may even spark "envy that may lead to accusations of witchcraft [ufiti] of those who are seen to benefit unjustly" (Watkins \& Swidler, 2013, p. 204). We-alongside others-are critical to how empowerment has become related mainly to internal qualities, as this approach redirects the responsibility for social and structural change to an individual level that may serve the very same status quo from which people-here women in particular-are supposedly empowered to break free from (Rutherford, 2018; Távara, 2019).

Women and girls are part of the community they live in, and as our analysis has shown, NGOs singling them-or any other social strata out-rocks the community balance, a balance that is often communally perceived as more important than achieving measures set from afar and above. Rural Malawian women are generally-and traditionally-considered subordinate to their husbands and their role as breadwinners and household heads (Anderson, 2015). Thus, the NGOs large focus on their empowerment and development rightly reflect the gendered inequality. Nevertheless, NGOs individualized development approaches abstract women and girls from their cultural and context specific knowledges and experiences. These interventions may thus undermine their ways of coping with a racialized, classed, and gendered society, and can lead to negative consequences for the "empowered" individual. Even though women most often are the main beneficiaries of NGOs individualized and gendered empowerment programs, they may also be the most vulnerable to the consequences of such individualized approaches. While the focus on women is meant to alter their position, the intended progress that the empowerment programs facilitate may make them the target of others envy, resentment and ufiti. Within psychology, increased attention to communal approaches to empowerment is therefore crucial. When development practitioners such as NGOs, implement theory and practice on 'targeted' people rather than in collaboration with and informed by them, they not only ignore their 'beneficiaries' lived experiences and knowledges, but also promote and reinforce dominant (often Western) assumptions of what counts as the "best and right way of doing things". This way of intervening may result in an erosion of local values and norms and can lead to a disruption of community life.

From a decolonial feminist stance, we argue that this imposing of Western individualized development and empowerment norms in terms of being, feeling, and knowing represent coloniality, embedded in and/or disguised as philanthropic "good will". This is echoed in criticism against psychology, where "the imposition of our own systems of knowledge upon other cultures and notions" has led to accusations against psychology of being imperialist in our attitudes "toward other cultures and has colonized them, supplanting their indigenous ways of thinking with western ideas” (Burr, 2015, p. 4). A serious turn is thus called for in both psychological and development practices, to incorporate context sensitivity and decolonial approaches. Many critical, decolonial and feminist perspectives in psychology reveal and challenge how primarily Western psychologized theories, practices, and concepts are exported to places and spaces 
outside the psychological field and affect individuals and groups (see Adolfsson \& Madsen, 2020; Bhatia \& Priya, 2018; Dhar, 2020; Dirth \& Adams, 2019; Kessi \& Boonzaier, 2018; Kiguwa \& Segalo, 2019). For further and future studies, we emphasize the need for researchers as well as activists and development practitioners to "take seriously knowledges embedded in communities" and the proactive methods of resistance and community-empowerment, and work with people-not on them (Segalo \& Fine, 2020, p. 8). As Fine and Torre (2016, p. 194) insist, for development initiatives to really be of benefit, they must honor and go in "intentional dialog with local experience/expertise"; be participatory and led by the local groups; attend to the local dynamics of power; address structural as well as social and psychological issues; and be self-consciously anti-racist/elitist and anti-colonizing.

\section{Limitations and Future Directions}

Our study has several limitations. First, the sample is small as well as non-representative, thus precluding statistical generalizations. However, that was not our aim, as we wanted to elicit rural Malawian views on empowerment and development. Such studies are rare and can contribute insights from a type of sample seldom represented in psychology. Second, getting rural Malawians' views on typical Western approaches, as represented by the NGOs, could be complicated by the first author's and Hannah's privileged positionalities as respectively an mzunga and an educated, middleclass Malawian. As before mentioned, despite having made explicit roles and objectives, participants asked Hannah and the first author to communicate their needs and wishes to NGOs, which illustrates the power asymmetry inherent in race and class, and the imperative need to reflect over intersectionality and positionality. The need for further studies on how individualized development/empowerment approaches may increase envy, enmity, and ufiti is critical. Second, empowerment is not the only psychology concept to have travelled into development practice and theory. Concepts like resilience, self-efficacy, self-actualization, and nudging, are also largely adopted by the development sector (see De Vos, 2012; Galárraga et al., 2018; Klein, 2016). Given psychology's implication with development approaches, more community based and informed research on the use of psychology within these contexts is necessary, as it can have large-scale consequences for the 'beneficiaries' on the ground.

Funding: The authors have no funding to report.

Acknowledgments: The authors have no additional (i.e., non-financial) support to report.

Competing Interests: The authors have declared that no competing interests exist.

\section{References}

Adams, G., Estrada-Villalta, S., \& Ordóñez, L. H. G. (2018). The modernity/coloniality of being: Hegemonic psychology as intercultural relations. International fournal of Intercultural Relations, 62, 13-22. https://doi.org/10.1016/j.ijintrel.2017.06.006

Adjei, S. B. (2015). Assessing women empowerment in Africa: A critical review of the challenges of the gender empowerment measure of the UNDP. Psychology and Developing Societies, 27(1), 58-80. https://doi.org/10.1177/0971333614564740

Adjei, S. B. (2019). Conceptualising personhood, agency, and morality for African psychology. Theory \& Psychology, 29(4), 484-505. https://doi.org/10.1177/0959354319857473

Adolfsson, J. S., \& Madsen, O. J. (2020). "Nowadays there is gender": "Doing” global gender equality in rural Malawi. Theory \& Psychology, 30(1), 56-76. https://doi.org/10.1177/0959354319879507

Adolfsson, J. S., \& Moss, S. M. (2021). "Even the NGOs never talk about ufiti ["witchcraft"]": A decolonial cultural psychology analysis of individualized development clashing with communal ways of being. Human Arenas. Advance online publication.

https://doi.org/10.1007/s42087-021-00230-1

Akomolafe, A. C. (2012). Decolonizing the notion of mental illness and healing in Nigeria, West Africa. Annual Review of Critical Psychology, 10, 726-740.

Anderson, E. (2015). Gender, HIV and risk: Navigating structural violence. New York, NY, USA: Palgrave Macmillan. 
Baird, S., Chirwa, E., McIntosh, C., \& Özler, B. (2010). The short-term impacts of a schooling conditional cash transfer program on the sexual behavior of young women. Health Economics, 19(S1), 55-68. https://doi.org/10.1002/hec.1569

Baloyi, L., \& Ramose, M. B. (2016). Psychology and psychotherapy redefined from the viewpoint of the African experience. Alternation Journal, 18, 12-35. Retrieved from https://journals.ukzn.ac.za/index.php/soa/article/view/1352

Bhatia, S., \& Priya, K. R. (2018). Decolonizing culture: Euro-American psychology and the shaping of neoliberal selves in India. Theory \& Psychology, 28(5), 645-668. https://doi.org/10.1177/0959354318791315

Braun, V., \& Clarke, V. (2006). Using thematic analysis in psychology. Qualitative Research in Psychology, 3(2), 77-101. https://doi.org/10.1191/1478088706qp063oa

Burr, V. (2015). Social constructionism. Hove, United Kingdom: Routledge.

Cornwall, A., \& Anyidoho, N. A. (2010). Introduction: Women's empowerment: Contentions and contestations. Development, 53(2), 144-149. https://doi.org/10.1057/dev.2010.34

De Vos, J. (2012). Psychologisation in times of globalisation. Hove, United Kingdom: Routledge.

Dhar, A. (2020). The slippery and the sane: Decolonizing psychology through a study of the Indian girl-child. Feminism \& Psychology, 30(3), 391-413. https://doi.org/10.1177/0959353520922419

Dirth, T. P., \& Adams, G. A. (2019). Decolonial theory and disability studies: On the modernity/coloniality of ability. fournal of Social and Political Psychology, 7(1), 260-289. https://doi.org/10.5964/jspp.v7i1.762

Estrada-Villalta, S., \& Adams, G. (2018). Decolonizing development: A decolonial approach to the psychology of economic inequality. Translational Issues in Psychological Science, 4(2), 198-209. https://doi.org/10.1037/tps0000157

Ferguson, J. (2006). Global shadows: Africa in the neoliberal world order. London, United Kingdom: Duke University Press.

Fine, M., \& Torre, M. E. (2016). The Public Science Project at the City University of New York, USA. In R. Tandon, B. Hall, W. Lepore, $\&$ W. Singh (Eds.), Knowledge and engagement: Building capacity for the next generation of community based researchers (pp. 186-196). Victoria, Canada: UNESCO / PRIA.

Galárraga, O., Harries, J., Maughan-Brown, B., Cooper, D., Short, S. E., Lurie, M. N., \& Harrison, A. (2018). The empower nudge lottery to increase dual protection use: A proof-of-concept randomised pilot trial in South Africa. Reproductive Health Matters, 26(52), 67-80. https://doi.org/10.1080/09688080.2018.1510701

Grosfoguel, R. (2002). Colonial difference, geopolitics of knowledge, and global coloniality in the modern/colonial capitalist worldsystem. Review - Fernand Braudel Center, 25(3), 203-224. http://www.jstor.org/stable/40241548

International Monetary Fund (IMF). (2017, July). Malawi: Economic development document (Country Report No. 17/184). Retrieved from https://www.imf.org/en/Publications/CR/Issues/2017/07/05/Malawi-Economic-Development-Document-45037

Kessi, S., \& Boonzaier, F. (2018). Centre/ing decolonial feminist psychology in Africa. South African fournal of Psychology/SuidAfrikaanse Tydskrif vir Sielkunde, 48(3), 299-309. https://doi.org/10.1177/0081246318784507

Keys, C., McConnell, E., Motley, D., Liao, L., \& McAuliff, K. (2017). The what, and the how and the who of empowerment: Reflections on an intellectual history. In M. A. Bond, I. Serrano-García, C. B. Keys, \& M. Shinn (Eds.), APA handbook of community psychology: Theoretical foundations, core concepts, and emerging challenges (pp. 213-231). Washington, DC, USA: American Psychological Association.

Kiguwa, P., \& Segalo, P. (2019). From where we stand: Reflecting on engagements with decolonial feminist community psychology. In F. Boonzaier \& T. van Niekerk (Eds.), Decolonial feminist community psychology (pp. 129-142). Cham, Switzerland: Springer.

Klein, E. (2016). Developing minds: Psychology, neoliberalism and power. London, United Kingdom: Taylor \& Francis.

Klein, E., \& Ballon, P. (2018). Rethinking measures of psychological agency: A study on the urban fringe of Bamako. The fournal of Development Studies, 54(8), 1284-1302. https://doi.org/10.1080/00220388.2017.1414187

Kurtiş, T., \& Adams, G. (2015). Interdependence and relationality across dimensions of culture and gender. Psychology and Society, 7(1), 29-50.

Lwanda, J. (2005). Politics, culture and medicine: Historical continuities and ruptures with special reference to HIV/AIDS. Zomba, Malawi: Kachere Series.

MacIntyre, L. M., Rankin, S., Pinderhughes, H., Waters, C. M., Schell, E., \& Fiedler, R. (2013). Socially disempowered women as the key to addressing change in Malawi: How do they do it? Health Care for Women International, 34(2), 103-121. https://doi.org/10.1080/07399332.2011.630116

Madsen, O. J. (2014). The therapeutic turn: How psychology altered Western culture. Hove, United Kingdom: Routledge. 
Makhubela, M. (2016). "From psychology in Africa to African psychology": Going nowhere slowly. Psychology in Society, 52, 1-18. https://doi.org/10.17159/2309-8708/2016/n52a1

Maldonado-Torres, N. (2007). On the coloniality of being: Contributions to the development of a concept. Cultural Studies, 21(2-3), 240-270. https://doi.org/10.1080/09502380601162548

Manuh, T., \& Anyidoho, N. A. (2015). 'To Beijing and back': Reflections on the influence of the Beijing conference on popular notions of women's empowerment in Ghana. IDS Bulletin, 46(4), 19-27. https://doi.org/10.1111/1759-5436.12152

McLafferty, I. (2004). Focus group interviews as a data collecting strategy. fournal of Advanced Nursing, 48(2), $187-194$. https://doi.org/10.1111/j.1365-2648.2004.03186.x

Mgbako, C. A., \& Glenn, K. (2011). Witchcraft accusations and human rights: Case studies from Malawi. The George Washington International Law Review, 43, 389-417.

Mignolo, W. D. (2007). Delinking: The rhetoric of modernity, the logic of coloniality and the grammar of de-coloniality. Cultural Studies, 21(2-3), 449-514. https://doi.org/10.1080/09502380601162647

Mkhize, N. (2004). Psychology: An African perspective. In K. Raele, N. Duncan, N. Mkhize, P. Kiguwa, \& A. Collins (Eds.), Self, community \& psychology (pp. 4-1-4-29). Landsowne, South Africa: UCT Press.

Moss, S. M., \& Hajj, M. H. (2020). Keepers of local know-how in conflict: Conversations between research assistant and researcher. In Y. Acar, S. M. Moss, \& Ö. M. Uluğ (Eds.), Researching peace, conflict and power in the field: Methodological challenges and opportunities (pp. 29-48) (Springer Peace Psychology Series). Cham, Switzerland: Springer.

National Statistical Office of Malawi. (2008). Population and housing census: Gender report. Retrieved from http:/www.nsomalawi.mw/images/stories/data_on_line/demography/census_2008/Main\%20Report/ThematicReports/Gender.pdf

National Statistical Office (NSO) of Malawi \& ICF. (2017). Malawi demographic and health survey 2015-16. Retrieved from https://dhsprogram.com/pubs/pdf/FR319/FR319.pdf

Nelson, G., \& Prilleltensky, I. (2010). Community psychology: In pursuit of liberation and well-being. New York, NY, USA: Palgrave Macmillan.

Nwoye, A. (2015). What is African psychology the psychology of? Theory \& Psychology, 25(1), 96-116. https://doi.org/10.1177/0959354314565116

Ogbonnaya, A. O. (1994). Person as community: An African understanding of the person as an intrapsychic community. The fournal of Black Psychology, 20(1), 75-87. https://doi.org/10.1177/00957984940201007

Pass, S. (2016). Oxford Chichewa Dictionary (5th ed.). Cape Town, South Africa: Oxford University Press.

Phillips, N. L., Adams, G., \& Salter, P. S. (2015). Beyond adaption: Decolonizing approaches to coping with oppression. Journal of Social and Political Psychology, 3(1), 365-387. https://doi.org/10.5964/jspp.v3i1.310

Pincock, K. (2018). School, sexuality and problematic girlhoods: Reframing “empowerment” discourse. Third World Quarterly, 39(5), 906-919. https://doi.org/10.1080/01436597.2017.1415141

Quijano, A. (2000). Coloniality of power and Eurocentrism in Latin America. International Sociology, 15(2), 215-232. https://doi.org/10.1177/0268580900015002005

Rappaport, J. (1987). Terms of empowerment/exemplars of prevention: Toward a theory for community psychology. American fournal of Community Psychology, 15(2), 121-148. https://doi.org/10.1007/BF00919275

Rutherford, A. (2018). Feminism, psychology, and the gendering of neoliberal subjectivity: From critique to disruption. Theory \& Psychology, 28(5), 619-644. https://doi.org/10.1177/0959354318797194

Sagner, A., \& Mtati, R. Z. (1999). Politics of pension sharing in urban South Africa. Ageing and Society, 19(4), 393-416. https://doi.org/10.1017/S0144686X99007424

Sakue-Collins, Y. (2021). (Un)doing development: A postcolonial enquiry of the agenda and agency of NGOs in Africa. Third World Quarterly, 42(5), 976-995. https://doi.org/10.1080/01436597.2020.1791698

Scott, J. C. (1990). Domination and the arts of resistance: Hidden transcripts. London, United Kingdom: Yale University Press.

Segalo, P., \& Fine, M. (2020). Under lying conditions of gender-based violence-Decolonial feminism meets epistemic ignorance: Critical transnational conversations. Social and Personality Psychology Compass, 14(10), 1-10. https://doi.org/10.1111/spc3.12568 Segalo, P., Manoff, E., \& Fine, M. (2015). Working with embroideries and counter-maps: Engaging memory and imagination within decolonizing frameworks. fournal of Social and Political Psychology, 3(1), 342-364. https://doi.org/10.5964/jspp.v3i1.145

Shivji, I. G. (2007). The silences in NGO discourse: The role and future of NGOs in Africa. Oxford, United Kingdom: Fahamu. 
Sustainable development goals knowledge platform. (2020). Sustainable development goal 5: Achieve gender equality and empower all women and girls. Retrieved from https://sustainabledevelopment.un.org/sdg5

Swidler, A. (2013). Lessons from chieftaincy in rural Malawi. In P. A. Hall \& M. Lamont (Eds.), Social resilience in the neoliberal era (pp. 319-345). Cambridge, United Kingdom: Cambridge University Press.

Swidler, A., \& Watkins, S. C. (2017). A fraught embrace: The romance and reality of AIDS altruism in Africa. Princeton, NJ, USA: Princeton University Press.

Távara, G. (2019). Engaging and contesting hegemonic discourses through feminist participatory action research in Peru: Towards a feminist decolonial praxis. In F. Boonzaier \& T. van Niekerk (Eds.), Decolonial feminist community psychology (pp. 27-41). Cham, Switzerland: Springer.

Tembo, M. S. (1993). The witchdoctors are not wrong: The future role and impact of African psychology on individual well-being. Paper presented at the Annual Meeting of the African Studies Association held in Boston, MA, USA.

UNESCO. (2013, January). Malawi country profile. Retrieved from http://uis.unesco.org/en/country/MW

Verheijen, J. (2013). Balancing men, morals and money: Women's agency between HIV and security in a Malawi village (Doctoral dissertation, University of Amsterdam). Leiden, The Netherlands: African Studies Centre. Retrieved from https://pure.uva.nl/ws/files/2290004/153363_00_Thesis_.pdf

Watkins, S. C., \& Swidler, A. (2013). Working misunderstandings: Donors, brokers, and villagers in Africa’s AIDS industry. Population and Development Review, 38, 197-218. https://doi.org/10.1111/j.1728-4457.2013.00560.x

WHO. (2019, March). Malawi country profile. Retrieved from https://www.who.int/countries/mwi/en/ 